\title{
«Nostalgieria»: Derrida przed i po Frantzu Fanonie`
}

\author{
Grant Farred \\ (Cornell University in Ithaca, NY, gaf38@cornell.edu)
}

„W dekolonizacji zawiera się żądanie pełnego ponownego rozpatrzenia sytuacji, jaką stwarza kolonializm" (Fanon 1985)

W Jednojęzyczności innego, czyli protezie oryginalnej Jacques Derrida podejmuje projekt Frantza Fanona explicite, z perspektywy immanentnej dziełu Wyklęty lud Ziemi. Derrida domyśla do samego końca proces dekolonizacji, podejmując pisanie symbolicznie i metonimicznie związane z tym samym miejscem, o które walczył Fanon. Tym miejscem jest Algieria. Jednojęzyczność ukazała się trzydzieści pięć lat po Wyklętym ludzie Ziemi (w 1961 r.; autor przystępuje do edycji niniejszego artykułu w cieniu 50. rocznicy tej publikacji) podąża za wezwaniem Fanona do „przeprowadzenia szczegółowej analizy sytuacji kolonialnej" (Fanon 1985/2012, s. 137). Ale Jednojęzyczność napisana po Wyklętym ludzie Ziemi nie analizuje „sytuacji kolonialnej" już po ustaniu kolonializmu, czyli - jak można by się tego spodziewać - $\mathrm{w}$ czasach postkolonialnych. (Aczkolwiek będę tu argumentował, że mimo wyparcia się tego faktu przez Derridę, Jednojęzyczność grzmi nieraz od uwag, które można określić co najwyżej jako postkolonialne, z uwagi na konwencję "chronologiczną"). Zamiast tego Jednojęzyczność analizuje sytuację kolonialną w trakcie trwania kolonializmu, tak samo, jak miało to miejsce u Fanona, nawet, jeśli mówi się o pewnych epizodach kolonialnych dyskretnie i nawet, jeżeli pisma Fanona sytuują się (wyraźnie) bliżej kresu francuskiej hegemonii aniżeli pisma Derridy. Refleksja Fanona skupia się na ostatniej dekadzie francuskich rządów kolonialnych w Algierii (mniej więcej w latach 1950-1960), podczas gdy refleksja Derridy

\footnotetext{
1 Publikujemy przekład artykułu Granta Farreda na podstawie jednorazowej licencji uzyskanej dzięki uprzejmości wydawnictwa Duke University Press. Anglojęzyczny oryginał ukazał pierwotnie się jako: Grant Farred. 2013. "'Nostalgeria': Derrida, before and after Fanon." South Atlantic Quarterly, Vol. 112, No. 1: 145-162. All rights reserved. Republished by permission of the copy right holder, Duke University Press, www.dukeupress.edu
} 
obejmuje okres od 1870 r. do połowy lat czterdziestych XX w. Rozpościera się ono pomiędzy dekretem Cremieux z 24 października 1870, który nadawał obywatelstwo Żydom algierskim i rokiem 1940 lub "1943" (Derrida nie jest ostatecznie pewien tej daty), kiedy to ponownie odebrano im to obywatelstwo, a następnie - ponownie je przywrócono.

Choć Wyklęty lud Ziemi jest kanonicznym tekstem antykolonialnym, Derrida ma prawo twierdzić, że - w krytycznym sensie - Jednojęzyczności innego to tekst odnoszącym się a priori do "sytuacji kolonialnej". Jako forma écriture , która myśli sama siebie, jako pisanie o („anty”-kolonialnym) pisaniu (tj. pisaniu, jakie stanowi jednojęzyczność), które nadejdzie jako odezwa skierowana do kolonializmu (do jego, tak bardzo skomplikowanych i pełnych przemocy efektów, bez reszty zależnych od języka, a zwłaszcza jednojęzyczności) Jednojęzyczność poprzedza zatem Wyklęty lud Ziemi. Jednojęzyczność jest ciałem maghrebskiego pisania o kolonializmie, które pojawiło się przed pisaniem Fanona i jego nakazem przystąpienia do walki przeciwko imperializmowi (a także przeciw jego następcy: nacjonalizmowi Trzeciego Świata). W tym sensie Derrida nalega, by Jednojęzyczność była możliwie "najbardziej franko-maghrebskim pisaniem" bardziej nawet aniżeli czyni to Amour bilingue (Miłość dwujęzyczna) Abdelkebira Khatebi'ego, do którego Jednojęzyczność w znaczącym stopniu nawiązuje. Jednojęzyczność kończy się dosłownie (mam tutaj na myśli to, że jej autor opisuje w niej ten moment kolonialnego spotkania) we francusko-maghrebskim momencie przed Fanonem, zanim ten rozpocznie własne pisanie po przybyciu do Maghrebu. W Jednojęzyczności spisano moment, zanim polityczny niepokój Fanona, tożsamy z ruchem prawdziwie antykolonialnym, stał się sprawą uniwersalną. sprawą, która dotyczyła wszystkich: kolonizatorów, kolonistów i skolonizowanych, o czym przypomina we Wstępie do Wyklętego ludu Ziemi Jean-Paul Sartre.

Być może jednak kwestię „przeprowadzenia szczegółowej analizy sytuacji kolonialnej" należałoby przeformułować w taki sposób, by spotkanie Derridy z kolonializmem (jeszcze nie całkiem bezpośrednie, ale już nader intensywne i pozwalające mu podejmować jego „deformacje, reformacje i transformacje” (Derrida 1998, s. 57) - jako wydarzenie, które zmusiło go do kwestionowania tej sytuacji, można było odpowiednio ująć. Sytuacja kolonialna bez wątpienia zakwestionowana została w Jednojęzyczności. Można nawet powiedzieć, że Derrida nigdzie nie potraktował skutków kolonializmu w sposób tak wymowny jak w Jednojęzyczności. Tak się stało w dużej mierze dzięki temu, że zajmował się Khatebim i Eduardem Glissantem (zwłaszcza w Poétique de la relation). 
Jednojęzyczność skonstruowana została jako dyskurs o sytuacji postkolonialnej. Zgodnie z wewnętrzną logiką tego eseju, znak „/" symbolizuje historyczną nieokreśloność tego, kiedy kończy się i zaczyna dany stan, niemożność ustalenia różnicy między postkolonializmem a tym, co go poprzedziło, i, co najważniejsze dla Jednojęzyczności w jej écriture - trudność w rozpoznaniu, jak należy „datować” moment pisania postkolonialnego. Tym samym, w terminologii Jednojęzyczności pytanie o sytuację kolonialną jest wielce obiecujące, albowiem podejmuje problematykę „sytuacji kolonialnej”, a jednocześnie nie pomija „zapytywania” i "kwestionowania" samego w sobie. Tym, co kwestionuje Jednojęzyczność, nie jest w gruncie rzeczy sytuacja kolonialna, ale nieświadomy podmiot kolonialny, który nie posiada własnego języka ani żadnego odpowiedniego, intelektualnego bądź afektywnego mechanizmu, który pozwalałby radzić sobie ze skutkami kolonializmu. Albo też podmiot kolonialny jest przerażony językiem, który do niego nie należy, jak zaznacza Derrida, a który mimo to stanowi jedyny dostępny dlań język: ponieważ podmiot kolonialny jest jednojęzyczny: „Mam tylko jeden język i nie jest to mój język", powiada więc Derrida (1998, s. 26). Autor Jednojęzyczności przedstawia podmiot kolonialny, który sam z siebie jeszcze nie zdążył siebie w ten sposób zidentyfikować i nazwać, i który zmaga się ze swą jednojęzycznością. W Jednojęzyczności Derrida odsłania własną kondycję młodego, "miejscowego Żyda” w Algierii, który był cząstką „zdezintegrowanej społeczności", rozproszonej i odciętej od swych sąsiadów, od samego siebie, od własnej historii (Derrida 1998, ss. 53-54). W rzeczy samej, kolonializm kwestionuje Derridę jako kogoś więcej aniżeli młodego żydowskiego chłopca. Napotykamy tu zasadniczo dwa, równorzędne "pytania", wobec których kolonializm stawia Derridę. Pierwsze z nich wiąże się z przedziwną kruchością jego skądinąd imperialnego obywatelstwa francuskiego. Podczas okupacji nazistowskiej we Francji Żydom z kolonialnej Algierii dano do zrozumienia, że „obywatelstwo jest na wskroś nietrwałe, świeże, zagrożone, bardziej sztuczne niż kiedykolwiek" (Derrida 1998, ss. 39). Obywatelstwo jest szczególnie zagrożone zwłaszcza wtedy, "gdy uzyskało się obywatelstwo w trakcie swego życia”, a jeszcze bardziej zagrożone jest, „,jeśli straciło się je w ciągu swego życia”. „Wraz z innymi utraciłem, a potem odzyskałem obywatelstwo francuskie. Straciłem je na lata, nie mając żadnego innego obywatelstwa. Najmniejszej jego namiastki, wyobraź sobie. 0 nic nie prosiłem. Ledwie się w tamtej chwili zorientowałem, że mi je odebrano - przynajmniej jeśli chodzi o tę legalną i obiektywną wiedzę, z jaką to tu przedstawiam" (Derrida 1998, ss. 39-40).

W kontekście walki z kolonializmem, twierdzi Fanon. „dekolonizacja nigdy nie przechodzi niepostrzeżona" (Fanon 1985, s. 16). W przypadku 301 
Derridy sprawa wydaje się (co nader ryzykowne) zarazem mniej i bardziej oczywista. To znaczy, do pomyślenia jest, że kolonializm przejdzie „niepostrzeżenie”: „Ledwie się w tamtej chwili zorientowałem, że mi je [tzn. obywatelstwo, uzup. tł.] odebrano”. „Utraciłem a potem odzyskałem obywatelstwo Francji": te stwierdzenia sugerują, że strata była czymś błahym, a zarazem traumatyzującym. Strata nie wryła się w pamięć z wielką mocą (osoba posiadająca obywatelstwo, której je odebrano, była zbyt młoda, by zdawać sobie $\mathrm{z}$ tego sprawę). A jednak niemożliwa jest strata bez rozpamiętywania. Jak sugeruje Derrida, żadna strata (szczególnie natury politycznej, jaką ma sporny przywilej obywatelstwa dla Żydów, dającego im prawo do bycia Francuzami) nie może być doznana bez żadnego skutku, nawet jeśli skutek ten jest jeszcze nieznany w momencie straty. (Z kolei moment rozpoznania straty czyni całe doświadczenie traumatycznym) Żadna strata nie przechodzi niezauważona, nawet jeśli potrzebuje ona, jak w opisanym przypadku, odpowiedniego czasu (czasu traumy: czasu, o który trauma się upomina i który zabiera), aby nabrać „legalnej i obiektywnej formy”, pozwalającej poddać pod dyskusję przemoc towarzyszącą pozbawianiu Żydów obywatelstwa. Jeśli politycznym zadaniem autora Wyklętego ludu Ziemi jest pisanie dekolonizacji po to, by mieć pewność, że nie przejdzie ona niezauważona, to, najogólniej mówiąc, Jednojęzyczność podejmuje się zadania polegającego na rozgłoszeniu kolonizacji, nawet jeśli póki co - w danej chwili niedostępna jest formuła pozwalająca odpowiednio ją wyartykułować. Idzie o uchwycenie skutków kolonizacji w taki sposób, by straty i zyski zostały zidentyfikowane i rozpoznane, mimo, że - jak wspomina sam Derrida - „Ledwo się zorientowałem w owym czasie”.

Ponadto, pozbawienie Żydów obywatelstwa okazuje się być kwestią jednojęzyczności. Derrida zdał sobie sprawę z głównego skutku utraty obywatelstwa dzięki temu, że zmieniła ona relację podmiotu do języka: „takie wykluczenia zostawiają ślad na owej przynależności i nie-przynależności do języka, na owym włączeniu do języka, na owym przypisaniu do tego, co jest spokojnie nazywane językiem" (Derrida 1998, s. 42). Po proklamacji odnośnie pozbawienia obywatelstwa można mówić już tylko o takiej żydowskiej przynależności do Algierii, która będzie nieuchronnie - lecz ryzykownie ufundowana na nie-przynależności. Czy kiedykolwiek mieliśmy do czynienia z przynależnością, która mogła uśmierzyć skutki nie-przynależności? W obrębie Jednojęzyczności nie ma mowy o istnieniu przynależności lub nieprzynależności, która traktowałaby francuski - jako jednojęzyczny język Derridy - jako „język pokojowy”. Takie przypisanie, takie powiązanie [pokojowości] z językiem francuskim okazuje się niemożliwe, wykluczone. 
Język francuski jest teraz napiętnowany, napiętnowany jest stosunek do niego i jego używanie przez tych, którzy nie mogą już zaznać spokoju w tym języku.

W tym sensie Jednojęzyczność to nic innego, aniżeli dyskurs o strachu, który zagnieździł się $\mathrm{w}$ języku, a konkretnie - $\mathrm{w}$ jednojęzyczności kolonializmu. Bardzo dobrze przystaje do tego konkluzja wyrażona przez Derridę w ostatnim wersie Jednojęzyczności, Derridę uwięzionego gdzieś między nieustannym zaangażowaniem i poświęceniem a kapitulacją wobec przemocy jednojęzyczności: „Umiem wreszcie nie być już zmuszonym rozróżniać między obietnicą a strachem" (Derrida 1998, s. 111). Istnieje więc możliwość dostrzeżenia, że nie ma niczego - w każdym razie niczego konkretnego - co różniłoby obietnicę od strachu. Ta różnica nie ma żadnego znaczenia, jeśli oni - oszuści, groźni adwersarze Derridy - okażą się być przerażająco podobni do kolonizatorów, jeśli nie tacy sami jak oni. Wszelkie obietnice pełne są grozy, albo przynajmniej zapowiedzi i znaków. Wszelka groza zawiera w sobie niewypowiedzianą obietnicę, która mogłoby zarówno odczynić, jak i spotęgować grozę.

Zadaniem Jednojęzyczności jest rozpoznanie kolonizacji. Poznanie jej w czasach grozy i jako grozy, i poznanie jej jako czasu, który „przyrzeka” jednojęzyczność - czasu, który unaocznia problemy myślenia jednojęzycznego. Jednojęzyczność „wyjaśnia” kolonizację w jej czasie bez względu na dostępność i niedostępność odpowiedniej „wiedzy”, bez względu na to, czy pisarz taką wiedzą posiada, czy nie - bez względu na to, czy „zna” postkolonializm, czy go nie zna. Może to być zadanie Jednojęzyczności po części dzięki temu, że pozostaje ona w dialogu z Wyklętym ludem Ziemi, dowiadując się z niego, w jaki sposób bez odpowiedniej świadomości swego czasu (co przecież niemożliwe) wytworzyć wiedzę o kolonializmie. Wytwarzanie tej wiedzy wymaga czegoś, co Derrida nazywa „świadectwem” (attestation): „porządek świadectwa sam świadczy o cudowności, o wiarygodnej niewiarygodności; o tym, w co trzeba wierzyć, tak czy owak, bez względu na to, czy jest wiarygodne czy nie" (Derrida 1998, s. 44). W przypadku niewiedzy, gdy podmiot „ledwie wiedział wówczas”, gdy wydaje się, że opór (o ile to jest odpowiedni opis dla kogoś, kto nie wie, lecz dąży na przekór temu „do tego, w co trzeba wierzyć, tak czy owak") sam w sobie jest czymś niepojętym, nakaz Fanona nabiera pełni mocy: albowiem to, co się wydarza, nie przechodzi niezauważone.

Powołaniem jest takie pisanie, żeby to, co jest, nie mogło przejść i przeminąć niezauważone. Drugim źródłem pisania kolonializmu w Algierii (już nieco mniej wzniosłym) jest stosowanie różnych powiązanych ze sobą nazw, takich, jak kolonializm i dekolonizacja, co sprawia, że Jednojęzyczność i Wyklęty lud Ziemi można rozważać razem, we wzajemnej korelacji. Można 303 
pomyśleć je razem nie dlatego, że ich autorzy pisali je z wnętrza tego samego doświadczenia (choć równie dobrze mogło być inaczej), lecz dlatego, że związało je ze sobą doświadczenie. Moglibyśmy je nazwać w sposób ułomny, a jednak prowokacyjny „Algierią” lub - za Derrida, którego esej temu właśnie daje wyraz - Nostalgierią. Przyszłość Algierii i dekolonizacji, a także Algierii, która ma dopiero nadejść, są niczym Fanon i Derrida, rozumiani jako ci, którzy wzięli na siebie zadanie „pisania” Algierii. Aby pisać kolonializm w Algierii, muszą pisać: pierwszy jako tubylec, który jedzie do Paryża, jako rewolucjonista przybyły na Martynikę przez Paryż, wreszcie jako „jakiś gość niezrozumiały, jakiś przybysz bez określonego pochodzenia" (Derrida 1998, s. 75). Muszą pisać jako inny, inny nawet dla nich samych.

\section{Nostalgieria}

Ciągle chyba o tym marzę, w mojej 'nostalgierii'. Powinienem był to nazwać moją niepodległością Algierii (Derrida 1998, s. 76).

Zarówno dla Derridy jak i Fanona Algieria stanowiła swoisty początek. Miejsce źródłowe, które już to $\mathrm{z}$ racji urodzenia, już identyfikacji ideologicznej wzbudza niepokój w obu autorach. Dla Derridy Algieria to miejsce, do którego musi dotrzeć (Algieria jest tym, do czego się przybywa), miejsce, dla którego musi pisać i które musi pisać nawet wówczas, gdy nie jest mu ono pisane. $\mathrm{Z}$ kolei dla Fanona jest to miejsce przytłoczone historią, w którym zakorzenić się musi walka o dekolonizację, z całym jej obiecującym potencjałem. Wobec tego nie jest to tylko „pisanie (écriture) w pewnym sensie tego słowa wokół którego [Fanon] krąży od dziesięcioleci”, lecz jest to Algieria lub „nostalgieria” (Derrida 1998, s. 57). Pisanie Algierii, pewien sens tej nazwy i słowa, jest celem, ku któremu zmierza Jednojęzyczność pisana przez Derridę, młodego Żyda, wy-powiadającego się z rozbitej, zdezintegrowanej społeczności. By móc pisać, bezwzględnie należy pytać (nawet bezgłośnie) w taki sposób, że separacja przestaje być konieczna. W jaki sposób myślimy lub piszemy, jeśli jakieś słowo nieustannie krąży dookoła, nienazwane, a mimo to immanentne? Takim słowem w rozmaitych artykulacjach pozostaje Algieria, stale pisana od nowa. Jest to stan, który Derrida i Fanon pojmują, choć nie w pełni. Stan skomplikowany przez fakt, że pragnienie pisania własnych początków podważa i kwestionuje rozpoznanie, że w Algierii są oni - i zawsze będą najwyżej gośćmi. Są gośćmi, albowiem Algieria jest najtrudniejszym rodzajem gospodarza: przyznaje rację tylko odpowiedniemu (to znaczy: powtarzanemu) pisaniu, pisaniu chwilowemu, pisaniu w danej chwili, pisaniu tego, co ma 
nadejść. Jedynie takie pisanie może uczynić Algierię zrozumiałą dla Fanona i Derridy.

Idąc dalej, pisanie to $\mathrm{w}$ obu wypadkach wypływa $\mathrm{z}$ problemu uzyskania obywatelstwa: Żyd w Algierii, ktoś w prowincji Martyniki, komu nadaje się obywatelstwo i kogo obywatelstwa się pozbawia, aby ponownie mu je zwrócić, [a] gdy tymczasem uzyskanie obywatelstwa jest dlań czymś niepojętym (życie jako francuski département francuski nie ma końca). Oto Algieria, o której „wciąż marzy” Derrida, która nawiedza go bezustannie i osacza tak bardzo, że może o niej myśleć tylko pod jej dziwacznym imieniem własnym: nostalgierią. Słowo to oznacza szczególny modus pisania politycznego zaszczepiającego nostalgię młodemu Żydowi, wyobcowanemu, a jednak z "kultury żydowskiej”. Chwiejne słowo „nie tożsame ani z narodem, ani państwem, ani religią, ani nawet - śmiem twierdzić - z autentyczną wspólnotą" (Derrida 1998, ss. 43-76). Nostalgieria zaświadcza o pragnieniu nadejścia nieautentycznej wspólnoty, o zobowiązaniu do pisania Algierii, której nie odpowiada nic poza nią samą (nie jest bowiem 'narodem, państwem, religią ani wspólnotą'), to znaczy: „odpowiada” jedynie coś, co Derrida nazwał pisaniem jednojęzycznym. Pisanie jednojęzyczne to dla myśliciela postkolonialnego jedyna dostępna możliwość pisania. Jest to pisanie, które mu pozostaje, choć nie jest to jego pisanie: „Mam tylko jeden język, i nie jest to mój język", jak głosi słynna deklaracja Derridy. Pisanie jednojęzyczne jest możliwe tylko pod tym warunkiem, że postkolonialny myśliciel potrafi rozpoznać, iż jego pisanie, a właściwie wszelkie pisanie (jednak w szczególności jego) wypływa ze stanu nostalgierii. Jest to pisanie „przybyłe od innego, pozostające dla innego, powracające dla innego” (Derrida 1998, s. 65). Tym samym, jednojęzyczność musi aspirować do pisania pionierskiego: pisania, o którym nie można niczego twierdzić, ale z którego początek bierze wszelkie pisanie - kolonialne, postkolonialne, post/kolonialne.

Tak pomyślane pisanie jednojęzyczne zachęca, jak to się dzieje $\mathrm{w}$ przypadku Derridy, do swoistego wślizgnięcia się w inność (przesadnej identyfikacji, która stanowi doraźne remedium przeciwko „zaburzeniu tożsamości" (Derrida 1998, s. 38)). Jego przejawem jest zrównywanie się młodej, żydowskiej tożsamości [self] z inną, która nie jest mu właściwie znana. Pewne jest tylko to, że coś najwyższej wagi „pochodzi od innego”, zawsze „tam pozostawało” i „tam powraca”. W tym sensie nostalgieria oznacza, że każde spotkanie Derridy z językiem, każde pisanie usilnie dąży do historycznej inności w Jednojęzyczności; inności, którą można pojmować jedynie w jednojęzyczności, w języku, który rości sobie prawa do pojedynczości, a jednak stanowi przykład wierności sobie [self]; w języku, którego echo 305 
pozostaje słyszalne w każdym języku, używanym - jak zobaczymy - w sąsiedztwie, w czasach, gdy Derrida był dzieckiem. To sprawia, że pojawiają się dwa rozbieżne, lecz równie doniosłe pytania: Jakiego rodzaju jest ten język? I jak to możliwe, żeby postkolonializm nie zdołał odkryć jednojęzyczności jako własnego języka?

To drugie pytanie zyskuje na ważności, ponieważ jednojęzyczność to język oryginalny bądź pisanie innego, które/który nigdy nie będzie moim „Mam tylko jeden język, i nie jest to mój język”. Jedynie poprzez umocowane w stracie - niewyobrażalnej stracie - pisanie jednojęzyczne „ci miejscowi Żydzi (...) obcy kulturze żydowskiej” umieją sobie radzić z „alienacją duszy, zadziwiająco bezpodstawną katastrofą, niektórzy powiedzieliby też: paradoksalną szansą” (Derrida 1998, s. 78). Tak naprawdę owa „paradoksalna szansa" nie jest jedynie zaaranżowanym przez Derridę myśleniem o alienacji, która wynikałaby jedynie z żydowskiej podatności na kolonialną władzę Francji, władzę nadawania, odbierania i przywracania obywatelstwa. "Paradoksalna szansa" to pisanie nostalgierii, nawiedzająca Jednojęzyczność. W każdym nostalgierycznym doświadczeniu - Derrida nie jest tutaj wyjątkiem - można znaleźć „alienację" i "paradoksalną szansę”. Tak właśnie mógłby brzmieć tytuł, stawiający pod znakiem zapytania to, co można czytać jako Jednojęzyczność innego. Mianowicie, „nostalgieryczna” moc sprawia, że nie tyle podważa ona Jednojęzyczność innego jako tytuł, lecz, że umiejscawia „nostalgieryczne” doświadczenie w centrum jednojęzyczności - w ten sposób, że jednojęzyczność musi być wpierw badana od strony nostalgierii. Każde kolonialne spotkanie musi zidentyfikować lub przynajmniej rozpoznać „zaburzenie tożsamości”, które rozgrywa się a priori w nostalgierii. Jakiego rodzaju pisanie pochodzi od innego, pochodzi ze względu na nikogo innego jak tylko innego?

Nostalgieria to nie tylko neologizm skonstruowany tak, by obejmować trwożliwe echa straty (nostalgia silnie aktywna), ale także jest to stan/kondycja opisująca jak ściśle związana jest strata, być może zbyt ściśle, z Derridy nostalgierskim doświadczeniem Algierii czasu wojny, która w żaden konieczny psychoanalitycznie sposób nie mogła go „ugościć” (nie mogła spokojnie odrzucić dekretu Cremieux; nie obroniłaby prawa Żydów do obywatelstwa; prawa do nie posiadania obywatelstwa w trybie bezzwłocznym bez słowa odebranego). Algieria czasu wojny nie była miejscem, w którym Derrida, jako młody Żyd na łasce imperialnej Francji i jej labilnych losów politycznych, mógł zamieszkiwać, lecz nie mógł także z niej zrezygnować. Albo używając dziwacznych, pełnych patosu słów Derridy: „Zachowuje to, co go zgubiło. I zachował również oczywiście to, czego nie zgubił" (Derrida 1998b, s. 59-60), a także, co ważniejsze, zachowuje to, co nie tyle „zgubiło go”, ile raczej 
zawiodło w jego odzwierciedlaniu (młodego Derridę poddano procedurze odebrania obywatelstwa: Francja czasu Vichy poświęciła go; marszałek Philippe Petain pozbawił go obywatelstwa, gdy naziści [sami] tego nie zrobili) lub najprościej to, co go zawiodło nie odzwierciedlając [go] w swojej (okupowanej i okcydentalnej/zachodniej) wizji siebie. Pod władzą Francji Vichy Algieria okazała się niezdolna lub nie będąca w stanie, by zdać sobie sprawę z „nostalgieryczności”.

„Nostalgierska” Algieria jest tą Algierią niezdolną do pisania sprawozdania z kolonializmu, w którym traumatyczne niepewności dekretu Cremieux i następujące po nim jego wycofanie i restytucja nie zostały zgubione. Nostalgieria jest tą Algierią, która nie mogła ochronić ani innego ani Derridy (ani Derridy jako innego dla innego) nawet od jego własnej straty przy czym w żadnym wypadku Francja Vichy nie uznałaby jego pozbawienia obywatelstwa za stratę. Jednakże to tylko jeden aspekt nostalgierii. „Nostalgieryczność" także ustanawia próbę odzyskania straty, w swych wielu często konsternujących, jeśli nie paraliżujących ekspresjach. Inną stronę „nostalgierii” stanowi jej polityczna wierność; deklaruje ona swoją wierność zdecydowana trzymać się straty, nawet jeśli pożądany obiekt odarty jest ze wspomnień - np. politycznych - o stracie, którą wygenerował. „Nostalgieryczność” przywraca stratę obiektowi jednojęzycznej miłości; nie można tego inaczej nazwać. Być nostalgierycznym oznacza znać naprzemiennie radość i ból miłości, znać zbyt intymnie, co to znaczy, że się kochało, [i] że miłość ta została odebrana, a następnie doświadczyć całkowitej anihilacji tej miłości przez samowolne, lecz nie do odzyskania, zapominanie. To jest to, co polityczna Jednojęzyczność stara się odczynić przez wyjaśnianie, co zawiera się w osiągnieciu niepodległości Algierii. To jest to, co prześladuje Derridy chaotycznie wstrzemięźliwą deklarację niepodległości; nie Algierii jako takiej, lecz nostalgierii: „Powinienem był to nazwać moją niepodległością Algierii" (Derrida 1998b, s. 76). Nie ma żadnej radości w tej deklaracji. Pozostaje jedynie głębokie poczucie, które nalegający wątek argumentacji Jednojęzyczności rozjaśnia, poczucie straty, która ma zostać ogłoszona idiomatycznie. Być nostalgierycznym oznacza być nawiedzanym przez poczucie pisania, które bardziej niż cokolwiek innego chciałoby by deklaracja niepodległości nie była konieczna, to jest deklaracja ogłoszona pod naciskiem „Powinienem był”. Intensywność straty domaga się by strata musiała (jako właściwa deklaracja niepodległości) ogłosić się pod swą własną nazwą nostalgieria. Suweren, bez względu na warunki, w których ta deklaracja miałaby miejsce, musi [to] ogłosić w swoim własnym imieniu publicznie światu, wszystkim, by słyszeli. Jednakże wciąż krąży pytanie, o ile jest możliwe 
i z pewnością trudne głoszenie niepodległości od Algierii, czy to w ogóle jest możliwe, by być niezależnym od nostalgierii?

Mamy jednakże do czynienia i z innym wyobrażeniem, które nawiedza tę deklarację. Albo też, formułując to inaczej, nostalgieria może być po prostu pragnieniem niepewnym jak siebie zadeklarować, pragnieniem suwerennego narodu-państwa, które jest kształtowane spośród takiego nagromadzenia straty. [Ta] nagromadzona strata ma właściwą sobie nazwę, prawie nie do zniesienia: nostalgieria. Czy jest możliwe pisanie postkolonializmu bez uwzględniania efektów nostalgierii? Czy jej efektem jest nawiedzanie, od Jednojęzyczności przez Wyklęty lud do Jednojęzyczności, postkolonializmu? Czym jest postkolonializm, jeśli nie „nostalgierią” pisaną wciąż od nowa przed sobą samą jako sobą? Czy postkolonializm może być jedynie zauważony w swym jednojęzycznym przebraniu jako nostalgieria? W terminologii Fanona ta kondycja/stan mogłaby być zrozumiana biblijnie „'ostatni będą pierwszymi.' Dekolonizacja jest weryfikacją tego zdania. I może właśnie dlatego dekolonizacja opisywana jest zawsze dekolonizacją udaną" (Fanon 1985/2012, s. 16). Tyle, że oczywiście, jeśli śledzimy argument Jednojęzyczności, dekolonizacja nie może być myślana tak ostrożnie, nie może być pomyślana jakby tego typu zapewnienie mogło być wystosowane. Czy może istnieć „ostatnie” pisanie, które nie zawiera śladów, bez względu na to jak fantasmagorycznych, pierwszego pisania? Czy pierwsze pisanie zawsze przychodzi przed ostatnim? Czy ostatnie nie jest już wpisane w pierwsze? Czy pierwsze i ostatnie nie są trudne do rozróżnienia? Czy dają się one, w tym pisaniu alfy i omegi, rozwikłać? Czy jedno nie jest podporządkowane drugiemu? A co jeśli, i to jest główne wyzwanie Jednojęzyczności, dekolonizacja nie jest możliwa ponieważ, ponad wszystko, jest tak głęboko zanurzona w języku innego? Czy taki język jest w stanie deklarować bez mocy (nawet bez intencji), by ogłaszać niepodległość? Jaki rodzaj deklaracyjności może deklarować sukces bez względu na warunki w obliczu tej niepokojącej siły, jaką jest nostalgieria?

W ten sposób „kwestionowanie sytuacji kolonialnej” nie prowadzi od Wyklętego ludu Ziemi do Jednojęzyczności Innego czyli protezy oryginalnej, lecz raczej od Jednojęzyczności do Wyklętego ludu do Jednojęzyczności. To Derrida prowadzi nas do Fanona, a nie odwrotnie. To jest to, co w terminologii Derridy, oznacza [moment], gdy postkolonializm nie jest współczesny sobie samemu. To Derrida, który myśli Algierię przed Fanonem w każdy niewspółczesny, „ana-chroniczny” (Derrida 2016, s. 48) sposób, który się liczy, jako, że nie może uwolnić się od nostalgierii - nie straci nostalgierii, bez względu na jego wymęczone deklaracje o uwolnieniu (czegóż innego deklaracje te mogłyby dotyczyć?). Ale ponieważ nostalgieria nie zadeklaruje 308 
jego straty, bez względu na pozory Derrida nie będzie stracony dla nostalgierii ani, być może, również i dla Algierii. Być „nostalgierycznym” oznacza, i teraz można to powiedzieć, zniweczyć wszelką możliwość niepodległości. Jednak nie oznacza to wszak bycia podległym. Przeciwieństwem niepodległości jest nostalgieria, życie marzeniem, życie tym, co żyje w marzeniach jako „nostalgieryczność”. Na swój własny sposób każdy „nostalgierczyk” jest rozpoznawalny poprzez jego marzenia; każdy nostalgierczyk jest oczywiście znany nam jako marzyciel. Nawet jeśli, jak Derrida jest świadomy, marzyciel nie posiada jako jej lub jego własnego języka: „Można mówić o jakimś języku tylko w tym języku. Nawet gdy się go umieszcza poza nim samym” (Derrida 1998b, s. 46). Naprawdę „nostalgierczyk” jest zakładnikiem, termin Derridy, języka - języka jednojęzyczności - oraz nostalgierii samej w sobie. Ani język ani nostalgieria nie będą podtrzymywały możliwości zewnętrza. A ten los (nie ma nic poza [tekstem]), jak wiemy, jest fundamentalny dla większego projektu Derridy.

\section{Jednojęzyczność}

Być może tylko za sprawą „paradoksalnej szansy” możliwe jest dla Fanona zamieszkanie w Jednojęzyczności (choć powinowactwo między dwoma Algierczykami - „miejscowym” i „adoptowanym”, nie może być jedną i tą samą prawdą, skoro to dwa odmienne przypadki; skądinąd jednak obaj postępują drogą Św. Augustyna, posługując się maghrebskimi figurami myślowymi). „Paradoksalna szansa”, która ma udział w wyalienowaniu kondycji dobrze znanej Fanonowi (ten paryski moment strasznego pouczającego samorozpoznania „Patrz murzyn!”) i którą [Fanon] bez ustanku bada w Wyklętym ludzie Ziemi oraz w Czarnej skórze, białych maskach, jest tym co powoduje myślenie o Fanonie obok Khatebiego i Glissanta, franko-maghrebskich i franko-karaibskich adwersarzach - prowokatorach Derridy w Jednojęzyczności. Wprawdzie może być tak, że walka Fanona jest po prostu wcześniejszym (o tyle, o ile Wyklęty lud... opublikowano przed Jednojęzycznościq̨) i późniejszym (Jednojęzyczność podejmuje problemy, które w pewnej mierze, choć nie zupełnie, były artykułowane w Wyklętym ludzie) wyrazem pisania jednojęzyczności przez Derridę. Wyklęty lud Ziemi dociera do kondycji kolonializmu sprzed i po Jednojęzyczności innego. W Jednojęzyczności autor pisze o kondycji kolonializmu przed i w pewien sposób całkowicie niedostępny dla Wyklętego ludu...; to kondycja, której Fanon nie może znać poza wiedzą o niej jako o denuncjacji kolonializmu. Nostalgieria prześladuje nie jedno, a oba te dzieła. Historycznie niepojmowalna (niewspółczesna) Algieria Derridy nie pokrywa się z żadną rozpoznawalną polityczną jednostką 
w Wyklętym ludzie, leży ona poza wyobrażeniem Fanona. [Jednocześnie] zobowiązanie Wyklętego ludu do produkcji dokładnie takiej politycznej formuły, którą Derrida uznaje za nieosiągalną, napisanie narodu-państwa algierskiego [i tym samym sprowadzenie] do istnienia przez autora Wyklętego $l u d u$, jest momentem przed i po, który znajduje jedynie fantazmatyczny adres w Jednojęzyczności. W ten sposób Fanon może być dostrzeżony w profilach Khatebiego i Glissanta w Jednojęzyczności. Tym samym Wyklęty lud Ziemi nie tyle nawiedza Jednojęzyczność, co jednojęzycznie żyje w tej książce - jako pisanie innego, które powraca, by niepokoić innego Jednojęzyczności. Postępując za Derridą, porządne myślenie [o] jednojęzycznym pisaniu Jednojęzyczności może być możliwe przez powrót do pisania innego jako ledwie rozpoznawalnego dla siebie samego. Taki powrót, taka retencja, (wewnątrz) innego jest, jak Derrida dobrze wie, „aktywna, dynamiczna, potężna" (Derrida 1998b, 56). Czy jest możliwe by pisać bez innego? (Czy jest możliwe by słyszeć „nostalgieryczność”, słowo wyprowadzone od Derridy, i nie myśleć jednojęzyczności postkolonializmu?)

Czy wszelkie pisanie, wszelkie pisanie postkolonialne, jest jednojęzyczne? Czy kiedykolwiek tytułowe postkolonialne „ja” (lub „mi/mnie” lub „my”) może w pełni zgłaszać pretensje do pisania postkolonialnego? Czy pisanie postkolonialne ma za przeznaczenie być, jak leniwie to zarysowuje Jednojęzyczność (Derrida, w bardzo sympatycznym nastroju, rozmawia, jak sam pisze, z przyjaciółmi, szczególnie z Khatebim), jedynym pisaniem, które „ja” ma, jedynym pisaniem, które „ja” może podejmować, a które, jeszcze, jeszcze wciąż, nie będzie moje? W ten sposób przynajmniej pisanie jednojęzyczne przynależy do niezdecydowania, które, jak Derrida twierdzi, „wpisuje groźbę w szansę, i strach w tożsamość gościa” (Derrida 1998b, 99). Wnikając w myśl Derridy nieco głębiej odkrywamy, że groźba wpisana w pisanie jednojęzyczne jest formą postkolonialnej autoimmunizacji: w pierwszej chwili postkolonialne, jednojęzyczne pisanie napełnia gościa: pisarza, Fanońskiego intelektualistę $\mathrm{w}$ typie kolonialnym bądź antykolonialnym - strachem. Pisać to znaczy ryzykować zakwestionowanie samego siebie, własnej tożsamości poprzez umiejętne rozpoznanie (pisanie) siebie. Któryż to gość nie wystawia się na ryzyko, nie odczuwa jakiegoś dreszczu przeszywającego płytko lub głęboko dreszczu, jakiejś zapowiedzi, która może się ziścić? A jednak nic innego poza pisaniem uczynić się nie da; postkolonializm trzeba przyjąć. Bez écriture nie ma tożsamości.

Pisanie jednojęzyczne to pisanie w pełni świadomości absolutnej grozy, z którą przychodzi się zmierzyć. Pisanie jednojęzyczne to pisanie, myślenie, bardziej konkretnie w języku, który nie jest twój własny, i nie posiadanie przy tym żadnego innego języka, żadnego innego sposobu 
myślenia. Przerażające. Nie ma żadnej szansy, niejako, by uniknąć tego spotkania, ponieważ istnieje jak rozpoznaje Derrida „terror w językach (jako, że istnieje w językach terror, łagodny, dyskretny lub krzyczący)" (Derrida 1998b, s. 47). Nie pozostaje nic innego do zrobienia, jak pisać jednojęzycznie, pisać w sposób zapewniający autoimmunizację. Dla postkolonializmu nie da się uciec od Algierii, ponieważ tylko dzięki konfrontacji z tym, co przeraża, możliwe jest pisanie innego - lub nawet pisanie jako inny. Jedyny sposób, by zrozumieć Algierię, czasem jako nostalgierię, oczywiście prowadzi od strony strachu, jako strony, z której język terroru się wyłania. To doświadczenie „terroru... to zdarzenie traumatyczne, bo idzie tu uszkodzenia ciała, o blizny, często o zabójstwa, czasem o mord zbiorowy” (Derrida 1998b, s. 50). To straszna rzecz musieć konfrontować się z terrorem, czyli „wydarzeniem traumatycznym" - przemoc zagraża przytłoczeniem i spustoszeniem społeczności - a jednak jedynie z „doświadczenia terroru” możliwe jest, by jednojęzyczność, „nostalgierskość” w pełni doszła do swej postaci, w sposób pełny mogła pisać samą siebie.

Być może właśnie z tego powodu Derrida deklaruje, jakby wypierając się strachu odnośnie swojej umiejętności sądzenia (wciąż rozpoznając ją jako istotnie pilną sprawę), „umiem wreszcie nie być już zmuszonym by rozróżniać między obietnicą a strachem" (Derrida 1998b, s. 111). Obietnica może zostać spełniona tylko poprzez strach. Inny jednojęzyczności jest zarówno obietnicą, jak i strachem. Jednojęzyczność, możemy być pewni, nie pozwala na myślenie siebie nigdzie indziej, nie może być pomyślana pod żadnym innym warunkiem niż wyparcie. Nie może być także pomyślana przez nikogo innego niż Derrida, ponieważ jedynie on - nie Khatebi, Glissant czy Fanon, możemy dodać - unika „posiadania” „języka ojczystego" (i to jest termin prawdopodobnie niewłaściwy). Algieria i nostalgieria są w rzeczywistości postkolonialnymi miejscownikami [ablative]. Z tego momentu, doskonale znanego pod swoją przerażającą, choć wyjątkową postacią Derridzie i Fanonowi, wyrasta postkolonializm; to $\mathrm{w}$ nim pisze postkolonialny [pisarz]. Nostalgieria jest miejscownikowym adresem postkolonializmu. Nostalgieria, z tego powodu (który uwzględnia oczywiście Algierię), jest stanem - kondycją postkolonializmu - za który Fanon i Derrida, w innej mierze i różnorakich zakresach, ponoszą znaczącą (jednojęzyczną) odpowiedzialność.

\section{Odkrywanie przez Écriture.}

W pisaniu jednojęzyczności, bez względu na to jak bardzo by protestował, Derrida nie może umknąć warunkom myśli, kierunkowi myślenia, ustanowionym przez Jednojęzyczność. Może ona i nie stanowi, jak Derrida 
nalega, „szkicu autobiografii... ani nawet nieśmiałej próby intelektualnego Bildungsroman" (Derrida 1998b, s. 108), lecz wokół Jednojęzyczności unosi się aura myśliciela - z braku lepszego terminu - odkrywającego postkolonializm, niespodziewanie bądź i nie. Jednojęzyczność jest pracą, w której Derrida zaczyna swoje myślenie o postkolonializmie, (za)wraca swoje myślenie ku swojemu początkowi. Jako praca postkolonialna charakteryzująca się abnegacją Jednojęzyczność podchodzi do postkolonializmu jako momentu, który nie może być nazwany bez zwrotu ku (mając na względzie ten moment w jego jednojęzycznej problematyce, moment, który niewątpliwie znamionuje narodziny jednojęzyczności) wydarzeniu ukazanemu $\mathrm{w}$ postaci trzech powiązanych ze sobą momentów: nadania/odebrania/ponownego nadania obywatelstwa; wydarzeniu, które rozpoczyna „nostalgierską” stratę. $\mathrm{Na}$ pierwszy rzut oka, jednojęzyczność jest politycznym efektem, który wymaga zwrotu ku, który jest także zawracaniem, zwrotem wstecz całe dekady, do przynajmniej października 1870 roku; zwrotem wstecz ku przynajmniej 1940. Jednakże, czas wydarzenie ma taki charakter, że te dekady, które rozciągają się poprzez rozmaite epoki polityczne, są skumulowane i „spotęgowane” poprzez wydarzenie w jedną całość - taka jest psychopolityczna siła tego wydarzenia. To wszystko wydarza się $\mathrm{z}$ powodu politycznej siły podejmowania postkolonializmu, trzymania go blisko, rozumienia - lub oglądania (lub jak Heidegger mógłby zasugerować, zbierając to razem) poprzez perspektywę nostalgierii.

Jako wydarzenie, Jednojęzyczność stanowi akt dochodzenia do postkolonializmu - nie po tym, gdy już się wydarzył (choć chronologicznie taka interpretacja jest niepodważalna), lecz w taki sposób, jak gdyby jeszcze do niego nie doszło, jak gdyby nie był współczesny sam sobie. Jednojęzyczność pod-chodzi do postkolonializmu tak, jakby on właśnie się wydarzał, i podczas gdy tak się dzieje, Derrida dochodzi do pisania swojej własnej kolonialności, która jest oczywiście, écriture postkolonialności. Tę postkolonialność uznaje się na krótki moment jako polityczne wyjaśnienie, jak Derrida pisze: „Judeofranko-maghrebska genealogia nie wyjaśnia wszystkiego, z pewnością nie. Lecz czy mógłbym wyjaśnić coś bez niej, kiedykolwiek?" (Derrida 1998b, s. 109). Co „genealogia” proponowana przez Jednojęzyczność rozjaśnia jest kwestia do osobnego zbadania, lecz jest jasne, że jednojęzyczne myślenie jednojęzyczne myślenie postkolonializmu - jest niemożliwe bez deklaracji (jako) Judeo-Franko-Maghrebczyk. Dzięki jednojęzyczności Derrida potrafi wyjaśnić samego siebie, a bez niej nie potrafiłby wyjaśnić czegokolwiek i kiedykolwiek. Nostalgierii nie tylko nie da się umknąć, jest ona całkowicie centralna dla myślenia Derridy, dla myślenia w języku, który prowadzi do innego, wreszcie - w języku innego. Nie może istnieć żadne myślenie, 312 
dekonstrukcyjne czy nie, które nie brałoby początku w uwikłaniu w jednojęzyczną dys-pozycję: „mam tylko jeden język , i nie jest to mój język”. Wciąż jednakże, możemy się zastanawiać, czy może postkolonialna jednojęzyczność nie jest prawdziwym pierwszym językiem Derridy? Czy to jest jego język ojczysty? Czy to do tego prowadzi jednojęzyczność? Wpierw do innego a następnie do mechanizmu niepewnego, wypierającego się, odrzucanego, miejscownikowego [ablative] samo-wyjaśnienia? Do tego słowa, wokół którego „krążył od dziesięcioleci”?

By zinterpretować Derridę w jego jednojęzyczności/Jednojęzyczności, zrozumieć Jednojęzyczność jako jednojęzyczność Derridy, koniecznie trzeba by wyrazić jego rozważania w twierdzeniu przez negację: „Nie mógłbym wyjaśnić czegokolwiek bez niej, kiedykolwiek". Czy nie jest to podpis języka ojczystego? Czy nie jest to język ojczysty podpisujący swą nazwę, czyniący siebie jednocześnie czytelnym i słyszalnym? Czy wszystkie języki postkolonialne są ufundowane na nostalgierii? Czy język ojczysty nie jest, przede wszystkim, językiem, myśleniem, mową, który jest nie najbardziej lecz najmniej objęty w posiadanie? Czy jest to język, nad którym mówiący - myśliciel - najmniej panuje? Czy jest najbardziej wrażliwy, ponieważ jest także, jeśli nie tym samym co, to podmiotem zakazu takim jak język ojczysty innego?

Język ojczysty innego nie mógł nie być bardziej znajomy, ponieważ, Derrida pisze: „język innego ...to był język sąsiada. Mieszkałem bowiem na obrzeżu dzielnicy arabskiej, na jednej z owych nocnych granic (frontier $d u$ nuit), niewidocznych i jednocześnie prawie nie do przebycia: segregacja była tam równie skuteczna jak subtelna" (Derrida 1998b, s. 61). A tym, co przychodziło do innego od jego „najbliższego bliskiego” (1998b, s. 61) (innego innego) nie było jedynie poczucie przepuszczalnej nieprzepuszczalności (granica jest zawsze [jakoś] przepuszczalna) i segregacja, lecz całkiem inna i równie niepokojąca jednojęzyczność: umiejętność kolonialnej Francji uczynienia arabskiego, bądź berberyjskiego, „językiem odjętym (...) najbardziej obcym" (Derrida 1998b, s. 65) w Algierii dla Algierczyków o pewnej pozycji, nie wykluczając Derridy. Gdziekolwiek się obrócił, czy to we własnym domu, w lycée, poprzez granicę nocy, Derrida stawał wobec jednojęzyczności, każdorazowo w formie domagającej się odeń suwerennego myślenia. Jednojęzyczność była zawsze pod ręką dla kolonialnego Algieru i wywoływała u Derridy - co nie jest żadnym zaskoczeniem - [poczucie] „pewnej osobliwej i niejasnej bliskości. Czasami zastanawiam się czy ów nieznany język nie jest moim ulubionym językiem” (Derrida 1998b, s. 65). A przy tym, jak bardzo nieznany jest ten ulubiony język? Ten język, który jest nieznany, lecz intymny, znajomy, zakorzeniony w subtelnie zakazanych spotkaniach w sąsiedztwie, wykraczający $\mathrm{z}$ jednego sąsiedztwa do 313 
następnego; jednojęzyczność, język, który ma za nic kolonialne zastrzeżenia i zakazy, które usiłują powstrzymać miłość przed pojawieniem się nocnej granicy (frontier de nuit). Wreszcie jednojęzyczny język to nostalgieria, czyli język wierny tylko sobie samemu, odrzucający rygory gramatyki, idiomatyki, struktury lingwistycznej, w pełni słyszalny jedynie we własnym rejestrze, mówiącym w swym własnym narzeczu. Wszelkie deklaracje niepodległości są jednojęzyczne: są napisane w języku, który nie należy do nich, a jednak nie mają oni żadnego innego, co oczywiście poddaje samo pojęcie niepodległości, Algierii czy też innego [kraju], zakwestionowaniu - przez kwestię, którą jest sytuacja kolonialna.

Język innego jest ulubionym językiem Derridy, tym, który jak pisze, „lubię go słuchać przede wszystkim poza wszelka 'komunikacją', w poetyckim dostojeństwie śpiewu lub modlitwy” (Derrida 1998b, s. 65). „Poetyckie dostojeństwo śpiewu lub modlitwy" nie jest poza komunikacją; to język wydestylowany do formy jednojęzyczności; to jest język, który jest „przedpierwszym językiem” (Derrida 1998b, s. 98) który, Derrida z pewnością to rozpoznaje, kieruje go ku Algierii jako miejscu „nostalgierskiego” początku, kieruje go, długo po 1940 lub 1943, ku Algierowi z Paryża. Owa „najpierwszość” dotyczy jednojęzycznego „francuskiego”, jeśli wolno dać taki opis, w którym wszystkie języki ojczyste - francuski, berberyjski, arabski i może nawet łaciński, i te wszystkie języki używane w klasach lycée w Algierze - cieszą się zmieszanym, „nostalgierskim” pierwszeństwem, patchworkowym pierwszeństwem. Jednakże jednojęzyczność poddaje się mówiącemu rzadko, w formie pieśni lub modlitw, których pierwotność sięga nawet przed „najpierwszy język". Istnieje, jak Derrida mówi, „jednojęzyczny upór" jednojęzyczności (Derrida 1998b, s. 89). Jednojęzyczność nie ustępuje łatwo ze względu na wierność sobie, nie-zawłaszczalność - „Mam tylko jeden język i nie jest to mój język". Jedynie jednojęzyczny podmiot, który stał się jednojęzyczny przez nostalgierię, rozumie, że inny „nigdy nie będzie mieszkał w języku innego, w tym drugim języku - gdy jest to jedyny język, którym się mówi, i którym mówi się z jednojęzycznym uporem w sposób zazdrośnie i surowo idiomatyczny" (Derrida 1998b, s. 98). Jednakże jednojęzyczność nie upiera się dla siebie. Jednojęzyczny upór jest, i to należy dostrzec, formą profilaktyki. Jednojęzyczność usiłuje chronić siebie przed pragnieniem zamieszkania przez innego, co jest powodem sprzeciwu wobec tłumaczenia i, możemy dodać, mówi za siebie w [sposób] „zazdrośnie i surowo idiomatyczny". W pragnieniu samo-ochrony można rozpoznać niezaprzeczalny pęd ku właściwej suwerenności: jednojęzyczność jest ugruntowana na wierności samej sobie. Tej właściwej suwerenności można się doszukać w tym, co Derrida nazywa „negatywnym dziedzictwem”: „nie jest 314 
to mój język". A jednak bezsprzecznie jego, Fanona, Khatebiego, Glissanta, Postkolonialności.

W obliczu marszruty jednojęzyczności (uporu, i jego) uporczywości, do Paryża, uporczywości Algieru w Paryżu, uporczywości Algieru poprzez nostalgierię, spowodowaną przez nic innego, jak sytuację kolonialną, jak mamy rozumieć umniejszanie przez Fanona, odrzucanie dyskursu Oświecenia jako „zbioru martwych słów”, pogrzebanych żywcem w „wartościach kultury śródziemnomorskiej”, które są niczym innym jak "martwymi i bezbarwnymi bibelotami”, podkreśla Fanon. Jaki jest ojczysty język Fanona? Jakimi słowami on, który - podobnie jak Derrida - pozostaje innym, odzywa się do innego? Jakie inne życia mieszkają w „martwych słowach”? To z tego powodu, zdaniem Derridy, o problemie sytuacji kolonialnej należy myśleć niezmiennie w trybie warunkowym i tymczasowym, albowiem „pewne przykłady alienacji 'kolonialnej' i historycznego zniewolenia (...) jeżeli się (...) nada odpowiednią orientację [może wybiegać] daleko poza tak określone warunki" (Derrida 1998b, s. 47).

Myśleć jednojęzycznie oznacza wiedzieć, że „struktura alienacji i bez alienacji, ta alienacja niezbywalna jest nie tylko źródłem naszej odpowiedzialności: buduje ona właściwość i własność języka” (Derrida 1998b, s. 49). Struktura niezbywalnej alienacji umożliwia mówienie językiem, który nie jest twoim własnym i, co więcej, pozwala brać udział w języku, który nie jest własnym - „mój język - jedyny, który słyszę, gdy mówię, i jedyny, którym się porozumiewam - to język innego" (Derrida 1998b, s. 48). To język pochodzący od, zachowany przez, powracający do innego, język, który ustanawia strukturę responsywności i umożliwia odpowiedzialność. Pierwszą pośród tych odpowiedzialności jest oczywiście twoja odpowiedzialność za innego, locus, który Derrida dzieli z Levinasem i, rzecz jasna, z Fanonem. Fanon mógłby pomstować na martwe słowa, ale - podobnie jak Derrida rozumie on, że wszelka odpowiedzialność rozpoczyna się wraz z językiem. Ta polityczna instancja pojawia się, kiedy Fanon kreśli obraz sposobu, w jaki kolonialny intelektualista - w pierwszym rzędzie dostawca „martwych słów” i stróż wierności Oświeceniu - może się przeistoczyć, poświęciwszy się walce o wyzwolenie. „Same formy organizacji walki narzucą mu słownictwo dotąd nie znane. Brat, siostra, towarzysz", powiada Fanon. Braterskie słownictwo walki (w tej samej mierze właściwe Oświeceniu, Marksowi i Fanonowi, co europejskiemu proletariatowi i antykolonializmowi) to język, który powierza sobie nawzajem wszystkich braci, siostry i towarzyszy. To jest źródło Fanońskiej i Derridiańskiej odpowiedzialności, to tutaj język odpowiedzialności się dla niego zaczyna: z ja które zna siebie, w pierwszej kolejności jako innego, jak podatne na przemoc kolonialnego reżimu. Może to 315 
być kwestią differance, nie małą kwestią, ale Fanon i Derrida wcale nie są niepodobni. Wszystko zaczyna się $\mathrm{z}$, jest zwrócone $\mathrm{ku}$, czerpie swoją tożsamość od innego.

Język zna siebie po pierwsze jako odpowiedzialność; odpowiedzialność nie może znać siebie bez języka. Wszelka odpowiedzialność rozpoczyna się $\mathrm{w}$ języku, który osłabia zakaz wprowadzony przez język kolonialny. „Nostalgierska” odpowiedzialność, by jakoś prowizorycznie to nazwać, nie ulegnie czarowi „martwych i bezbarwnych bibelotów” ani też nie przestanie wskazywać na innego, ponieważ jej kolebką jest język jednojęzyczności. Pomimo całkowitej demaskacji Fanon rozumie, jak wskrzesić „martwe słowa”, reanimując je zastrzykiem jednojęzyczności - jak myśleć i mówić w języku, który nie jest twój. Dlaczego Fanon opiera się, nie bacząc na własną, nieusuwalną alienację? „Terror w języku” zaczyna się od drobnych szkód, a kończy na „zbiorowych mordach”). A gdy sprawia, że język mówi przeciwko francuskiemu po francusku, to staje się językiem przemocy po francusku? „Nie można”, to pewne, „mówić o języku nie w tym języku”. Nie ma bowiem niczego poza tym językiem. Z tego powodu Fanon, podobnie jak Derrida, zostaje jednym z „zakładników francuskiego” języka. „Nostalgierski” podmiot - nadmienia Derrida - jest zakładnikiem już „na zawsze; coś mi z tego zostało, na próżno wiele podróżuję" (Derrida 1998b, s. 42). Zakładnik, jak można mniemać, ma prawo myśleć o najbardziej dotkliwym rodzaju przemocy ze strony swoich oprawców. Ale język, niczym Wyklęty lud, wypowiada sam siebie, poza nim nie ma nic. Wyłącznie dzięki jednojęzyczności, bez względu na jej „upór” i marzenie o suwerenności, zakładnik może swoje położenie przetrzymać, aby później przemówić językiem innego.

O ile Fanońskie zakwestionowanie otwiera postkolonialne drzwi Derridiańskiej nostalgierii, o tyle jednojęzyczność Derridy umożliwia zrozumienie, jak Wyklęty lud i Jednojęzyczność, każde na swój sposób, usiłują przywołać pisanie do wnętrza języka (Derrida 1998b, s. 101), a także tego, jak pisać jako inny w języku innego, kiedy pisanie wydaje się zupełnie niemożliwe. Pisanie przez innego w języku innego oznacza przy tym opowiedzenie się za i przeciwko pragnieniu czegoś istotowo suwerennego. Takie pisanie staje się „nostalgierskim” i - jako pisanie właśnie - „zatrzymuje to, co stracone", czyli Algier, zdając sobie sprawę z tego, że nie sposób zadomowić się w języku innego i że bez względu na to, jak bardzo nieszczelna okazuje się nocna granica (frontier de nuit), nadal łatwo zidentyfikować i uchronić jednojęzyczność. Berberyjski i arabski może i przebijają z zaśpiewów i modłów, wzbudzając nostalgierię, lecz tym, co myślicielowi jednojęzycznemu udaje się niekiedy najlepiej jest krążenie dookoła poprzez pisanie. Wyklęty lud Ziemi i Jednojęzyczność stanowią wytwory takiego „nostalgierskiego” krążenia. 
Obydwa dzieła toczą walkę $\mathrm{z}$,jednojęzycznym uporem”. Powinowactwo między nimi opiera się na zrozumieniu tego, że pisać postkolonializm to pisać jednojęzycznie. Jak zwykle czai się tu (lurks) obietnica, że choć posiada się tylko jeden język, to na tę jedyną, jednojęzyczną chwilę może on stać się moim. Będąc w potrzasku (lurking), prędzej czy później natykamy się na innego i jego kwestię.

\section{Przypisy:}

1. Nie sposób rozpoznać jego status. Czy to jest on kolonialny, czy postkolonialny? Jeśli nie da się tego rozstrzygnąć na pewno, wówczas należy to uczynić w poszanowaniu dla nierozstrzygalności - jako postkolonialny.

Wszystkie przypisy w niniejszym przekładzie zaczerpnięto z polskich tłumaczeń, jeśli takowe były dostępne (uwaga od tłumacza).

Tł. Agata Mergler

\section{Bibliografia:}

Derrida, J. 1994. Specters of Marx: The State of the Debt, the Work of Mourning. Trans. P. Kamuf. London: Routledge.

Derrida, J. 2016. Widma Marksa. Stan długu, praca żałoby i nowa Międzynarodówka. Tł. T. Załuski. Warszawa: PWN.

Derrida, J. 1998a. Monolingualism of the Other Or the Prosthesis of Origin. Trans. P. Mensah. Stanford: Stanford University Press.

Derrida, J. 1998b. "Jednojęzyczność innego czyli proteza oryginalna". Tł. A. Siemek. Literatura na Świecie, Vol. 11-12: 24-113.

Fanon, F. 2004. The Wretched of the Earth. Trans. R. Philcox. New York: Grove Press.

Fanon, F. 2012/1985. Wyklęty lud Ziemi. Tł. H. Tygielska. Przedmową poprzedziła E. Rekłajtis. Warszawa: Maoistowski Projekt Dokumentacyjny.

Sartre, J.-P. 2004. "Preface by Jean-Paul Sartre" to F. Fanon, The Wretched of the Earth. Trans. R. Philcox. New York: Grove Press. 


\section{Grant Farred \\ (Cornell University in Ithaca, NY, gaf38@cornell.edu) \\ «Nostalgieria»: Derrida przed i po Frantzu Fanonie}

Abstract: Monolingualism ofthe Other; or, The Prosthesis of Origin (MO) Jacques Derrida (1998) takes up Frantz Fanon's project in The Wretched of the Earth $(W E)$ at its very core. Derrida thinks "decolonization" from the very place for which Fanon- and from which Derrida, symbolically and metonymically-struggled and wrote, Algeria. The author explores the experience of writing "nostalgerically."

Keywords: Derrida, Fanon, nostalgeria, monolingualism

Ethics in Progress (ISSN 2084-9257). Vol. 1 (2016). No. 1., Art. \#19, pp. 299-318.

doi: 10.14746/eip.2016.1.19 